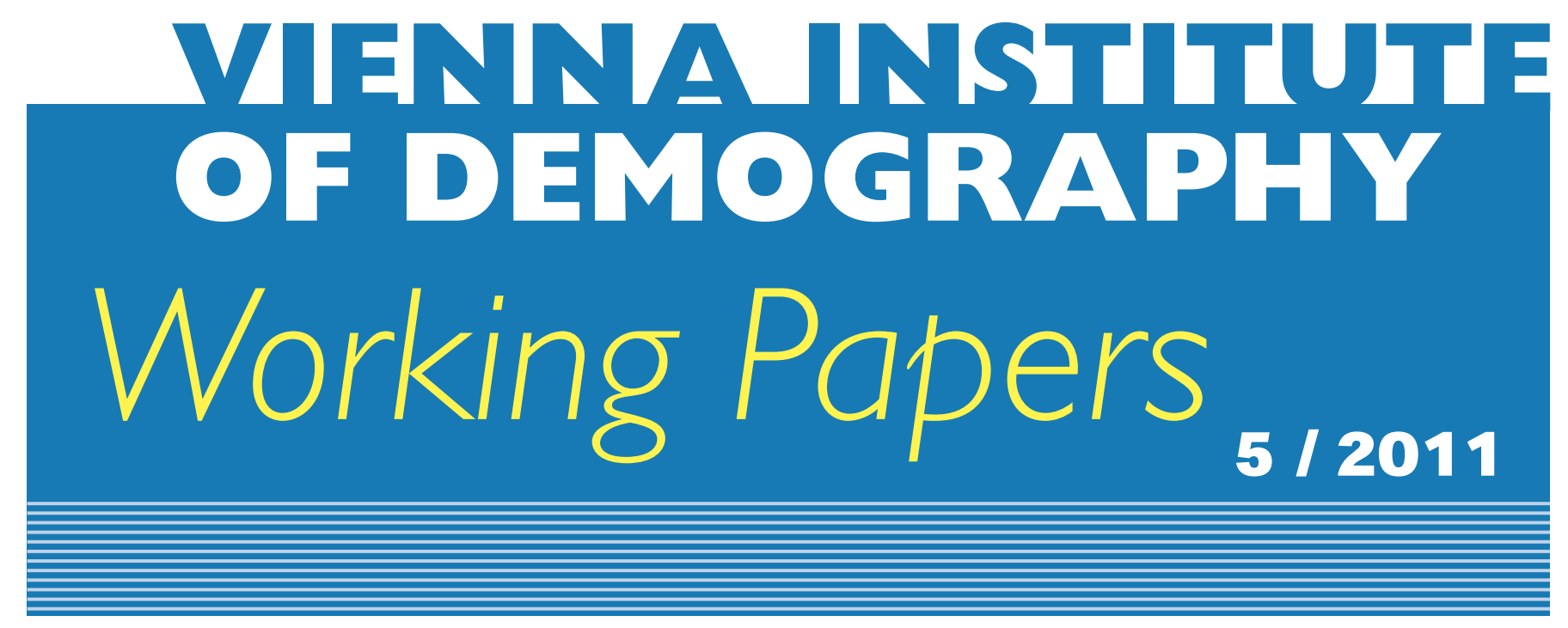

Bilal Barakat

\title{
Time is Money: Could Deferred Graduate Retirement Finance Higher Education?
}

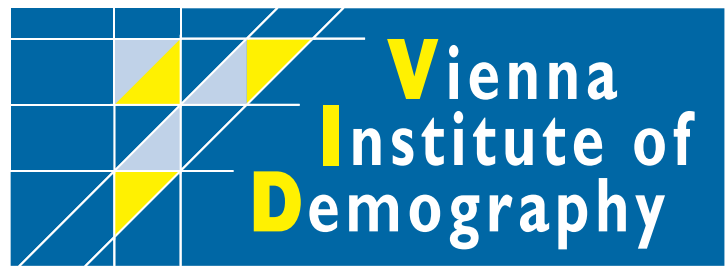

Vienna Institute of Demography Austrian Academy of Sciences

Wohllebengasse 12-14

A-I040 Vienna · Austria

E-Mail:vid@oeaw.ac.at

Website: www.oeaw.ac.at/vid

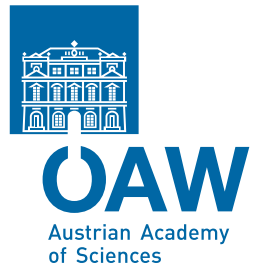




\begin{abstract}
Higher education is never free — the question is: who should pay for it? Current policy debates in Europe are increasingly focusing on raising the share of private funding. To date, policy discussions have centred on a relatively small number of alternatives, namely full public funding, tuition fees, either up-front or delayed and income-contingent, or a surtax on graduate incomes. Here, I present an alternative that, to my knowledge, has not been suggested previously, but sidesteps some important objections against other forms of private contributions. The basic idea explored here is to increase the statutory retirement age for higher education graduates relative to non-graduates. In principle, the resulting decrease in future public pension liabilities can be converted into increased funds for present spending on higher education. In this first discussion of the above proposal I consider important caveats, perform an order-of-magnitude estimate of financial feasibility, i.e. whether deferred graduate

retirement (DGR) could potentially raise sufficient funds to replace tuition fees, and discuss advantages and disadvantages compared to more established policy options. I conclude that, at least in the European context, DGR is potentially feasible both financially and politically, has a number of desirable properties compared to the alternatives, and deserves more serious investigation.
\end{abstract}

\title{
Keywords
}

Higher education, cost-sharing, retirement age.

\section{Author}

Bilal Barakat is a Research Scholar at the Vienna Institute of Demography (VID) of the Austrian Academy of Sciences, and a researcher in the World Population Program at the International Institute for Applied Systems Analysis (IIASA), Laxenburg, Austria, and Team Leader for Education Policy \& Planning at the Wittgenstein Centre for Demography and Global Human Capital. Email: bilal.barakat@oeaw.ac.at

\section{Acknowledgements}

For their helpful comments and suggestions I would like to thank Jesús Crespo Cuaresma, Michael Kuhn, Wolfgang Lutz and Klaus Prettner. 


\title{
Time is Money: Could Deferred Graduate Retirement Finance Higher Education?
}

\author{
Bilal Barakat
}

\section{Introduction}

Higher education is never free — the question is: who should pay for it? To ask this question is not in itself an act of commercialising higher learning, for it arises regardless of whether we frame the benefits of higher education (HE) as a possibly intangible and unmeasurable contribution to the public good or in purely economic terms. It is the answers that will differ, not the question. Current policy debates in Europe are driven by the notion of cost-sharing, that is to say, raising the share of private funding. To date, such debates have centred on a relatively small number of policy instruments, namely full public funding, tuition fees, either up-front or delayed and income-contingent, or a surtax on graduate incomes.

This is not the place to engage with arguments why HE should be a public funding responsibility as a matter of principle (Tilak, 2009). The present purpose is to show that given a policy decision to increase the share of private funding, there is an alternative that has not been suggested previously, but that deserves serious consideration because it sidesteps some important objections against other forms of private contributions.

The basic idea explored here is to increase the statutory retirement age for HE graduates relative to non-graduates. In principle, the resulting decrease in future public pension liabilities can be converted into increased funds for present spending on HE. In the following, such a scheme will be referred to as Deferred Graduate Retirement (DGR).

The principle is most relevant in a context where public pensions are substantial, and the private contribution to HE funding is not already comparable or exceeding public funding. In effect, this results in a focus on OECD member countries, especially European ones.

The issue is framed here in terms of HE policy, not of public welfare economics. In a different context, the financial feasibility of the policy would be a necessary "box to tick", but the potential effects of different $\mathrm{HE}$ financing instruments on aggregate welfare, human capital investment, or labour supply, say, would take center stage. Here, these are treated as side-effects. For the time being, the modest aim is merely to examine whether any of the likely effects are so obviously undesirable as to eliminate DGR from further consideration, not whether they are in any sense optimal. 
The presentation is organised as follows. Following a brief survey of the most commonly discussed HE funding and financing instruments, major lines criticism from a number of perspectives are outlined, in order to anticipate the standards that DGR will be measured against. The characteristics of the DGR scheme are then explained in some more detail. A rough order-of-magnitude calculation serves to establish the potential financial feasibility of the scheme, and possible directions for a more detailed economic analysis are highlighted. I conclude by discussing the expected effects of DGR on the HE system and by speculating on the scheme's policy implications.

\section{Background: Debating Private Contributions to Higher Education Funding}

Let us very briefly rehearse the main arguments voiced for and against existing HE funding instruments. Not to arbitrate between them, but to extract criteria for assessing DGR.

\subsection{Established funding instruments}

The academic and policy discourse focuses on a relatively small number of financing instruments. These can be broadly characterised as: full public funding, up-front fees, delayed income-contingent fees, and a graduate tax.

Full public funding means that students are not charged a contribution either at time of study or after graduation, other than possibly administrative fees of a marginal magnitude. This does not rule out (possibly substantial) indirect costs borne by the student. The largest is the opportunity cost of income foregone during the time spent studying. Neither does full public funding of instruction costs necessarily entail cash subsidies to students and/or their families such as tax breaks, child allowances for adult children in full-time education or subsidised health insurance, even if in practice it frequently does.

Tuition fees might either be charged up-front or following graduation, with the repayment schedule possibly income-dependent. Conditional on the income threshold below which no payment is required, a distinction may be made between income-contingent loans and human capital contracts, but for present purposes, the difference is inconsequential.

A graduate tax is an income surtax levied on graduate incomes above a given threshold (such as the average non-graduate income level), possibly for a limited amount of time following graduation, such as 30 years (as foreseen in the case of England in the recent "Browne Report" (Browne et al., 2010).

Occasionally, progressive general income taxation is portrayed as effectively constituting an indirect graduate tax, because the average graduate pays tax at a higher rate than the 
average non-graduate with a lower mean income (Vandenberghe, 2005). However, apart from the lack of definitional contingency on graduate status, receipts from the general income tax on the "excess" average income of graduates is not linked in any way to HE spending. General progressive income taxation is therefore not considered as an additional private funding instrument here.

In practice, a mix of instruments is deployed. Fees coexist with subsidies and a mixture of grants and loans, which in turn might be subject to an income-contingent repayment schedule. In addition, the boundaries between instruments may be blurred, depending on the precise modalities and also on perspective. For example, Shen and Ziderman (2008) have found that most student loan schemes include a significant "hidden grant" component. Also, fees may be collected up-front from the institutional perspective, but in the presence of a universal low-interest loan scheme, constitute a delayed payment from the student perspective.

While delayed income-contingent fees or loan schemes may resemble a tax, the debt is still owed by a particular individual for a given course of study, and its exact level may depend on the characteristics of either. By contrast, under a graduate tax scheme in the strict sense, repayment does not stop once a certain cumulative amount has been paid. Graduates end up paying different total amounts, but the source of this variation are their ex-post income levels, not differences in their choice of course or differential ability to avoid interest payments.

\subsection{Assessment criteria}

Access and student choice

In a (neo-)classical economic paradigm, tuition fees will typically be greatly compensated in terms of higher life-time income, making higher education a sensible investment even if students have to go into debt to pay for it. But even from this perspective, optimal investment in $\mathrm{HE}$ can only occur if potential entrants do not face liquidity constraints. High fees can only be justified in the presence of student loans and grants, at least for those otherwise least able to afford enrollment. In practice, the economic rationale of "high fees, high aid" often fails to convince, because the first part of the formula is implemented much more readily than the second. In the process of marketization of HE in the US, for example, a real increase in aid, much less one commensurate with rising fees, was not forthcoming (Hossler et al., 1997).

More interesting is criticism of cost-sharing focusing not on the improper implementation of classical economic reasoning but challenging its premises. For most claims that fees are too high, this is not to be understood as claiming they make HE a bad financial investment, but that they are too high not to represent a psychological discouragement for risk-averse potential students, and that this effect acts disproportionally on those from low 
socio-economic status (SES) backgrounds, who are unwilling to begin their working life with significant debt, however economically rational it might be to do so. Research in behavioural economics confirms that scholarships and grants have to over-compensate fees in order to counter the psychological barrier to enrolment created by fees among potential students from low-SES backgrounds (Vossensteyn, 1999). Indeed, such potential entrants are known to be more price-averse, more debt-averse, and perceive greater academic risk, i.e. are less confident they will successfully graduate (Asplund, Adbelkarim and Skalli, 2008), even if some of these characteristics are shared by "unsure" potential entrants generally, independently of social background (Davies, Mangan and Hughes, 2008). Even when these mechanisms are explicitly included in their formal models, classical price-response and human capital theory alike struggle to explain why many students work part-time, even if doing so means they have to wait longer to earn a graduate salary, and if this financial loss greatly exceeds their earnings as casual student workers, for example.

These observations on are only superficially contradicted by studies showing surprisingly little impact of fees on the aggregate demand for HE. First, even these studies frequently find larger effects for low-SES students (of which there are too few to significantly affect total demand). Second, the deterrent effect may be underestimated if the potential endogeneity of tuition fees is not taken into account (Neill, 2009).

In addition, there is a concern that when prospective students have to ensure their degree is a financially profitable investment, they are forced into degrees that offer high income premiums, instead of those they are inherently interested in.

Distributional effects and equity

Progressive redistributive effects of HE financing instruments are on the whole regarded as desirable. An intensely debated question is whether public funding for HE, rather than benefiting disadvantaged groups, is actually a regressive distribution of resources (DablaNorris and Gradstein, 2004). This would be the case if the higher uptake of public HE among middle-class youth resulted in a net transfer of resources from low-income tax payers to middle-class families.

While, if true, this would constitute a strong argument against the claim that social justice unambiguously comes down on the side of publicly funded $\mathrm{HE}$, the empirical evidence remains ambiguous (Asplund, Adbelkarim and Skalli, 2008; Callan, Smeeding and Tsakloglou, 2008). Without attempting to settle this question, we take note that a HE financing instrument should not be prima facie regressive.

While in terms of optimality in formal models, many studies conclude in favour of a graduate tax, in practice a pure graduate tax has nowhere been implemented (Asplund, 
Adbelkarim and Skalli, 2008). Instead, income-contingent loan schemes have been preferred. Part of the reason is that the redistributive effect of a pure graduate tax is excessive. Those with high incomes might "repay" a total amount vastly disproportionate to the cost of their own instruction. Even if such a significant income transfer is deemed desirable, this aim should clearly be pursued within the scope of an explicit income policy, not implicitly through HE funding (Vandenberghe and Debande, 2007).

Higher education governance

The expected impact of private contributions on HE institutions (HEIs) has served as arguments both for and against increasing their role.

Proponents appeal not only to economic (that doing so corrects incentives for suboptimal investment in human capital) and fiscal arguments (to relieve pressure on severely constrained public budgets), but also the expectation that institutional management would improve (Johnstone, 2004). As paying customers, students can expect and demand better quality of service from HEIs, who become more responsive to student needs and demand for different types of courses.

Opponents may agree on the impacts, but draw the opposite conclusions. Yes, HEIs will be run more like businesses, but doing so undermines their ethos as places of higher learning and their "higher purpose" to contribute to social inclusiveness and justice (Schwartz, 2011), and as hybrid institutions, "neither scientific nor commercial goals can be fulfilled properly" (Häyrinen-Alestalo and Peltola, 2006, p. 276). In any case, some of the assumed benefits might alternatively be achieved by channelling public funds through private hands (Williams, 1988).

This debate will not be pursued further here. As is argued below, one property of DGR is that it neither presupposes nor determines any particular model of HE governance, and therefore helps to disentangle this issue from that of funding.

\section{Deferred Graduate Retirement}

To summarise the above, an ideal HE financing mechanism satisfies all of the following conditions: It should not constrain student choice, nor create psychological obstacles to enrolment. Private contributions should be proportionate (n.b. not necessarily proportion $a l$ ) to the benefit derived and the ability to pay, and allow for risk-pooling. It should neither be regressive nor radically progressive in its redistributive consequences. Finally, it should not by itself predetermine other aspects of HE policy. 
DGR does not dominate on all these criteria. However, it represents a combination of compromises that is distinct from those of the alternatives.

\subsection{Definition}

The Deferred Graduate Retirement approach to HE funding consists of raising the retirement age for graduates, in order to convert the resulting future public savings into presently available resources for $\mathrm{HE}$ funding.

If an individual would otherwise become eligible for a state pension at age $a$, then for a HE graduate, this would rise to $a+x$, with $x$ likely to be between 1 and 3 years. For graduates, this represents the new state pension age for all purposes, including for the calculation of early retirement benefits. The diminished future public liability for pension payments between $a$ and $a+x$ represents a public asset. DGR does not by definition specify the conversion of this asset to present funds. If HE funding remains constant, a "pure shift" from public to private funding has occurred. However, if the government does cash in the future asset, the gain must benefit HE, or else we do not have a case of DGR as a HE financing instrument.

The above describes the principal idea behind DGR, but clearly leaves the actual policy under-determined. For example, there are different possibilities for how to adapt the pension schedule. Will it be (left-)truncated, or shifted? However, the implications of such details are for the most part purely financial. The concern whether "the numbers add up" and DGR could actually serve its intended purpose, is addressed separately in Section 4.

At this stage, the modest aim is to introduce into the debate the DGR principle in terms of HE policy. In order to simplify the initial exposition, and not to get sidetracked prematurely, a stylised pension system is assumed, that is fully public, "pay as you go", and where retirement timing is driven by statutory age requirements. The reader is asked to bear with this simplification for now. In later sections I will begin to discuss some implications of relaxing these assumptions.

\subsection{Distinctiveness}

DGR may appear equivalent to charging fees but allowing individuals to borrow against their future pension stream. In fact, the latter policy would be more general: graduates could use these borrowed funds to pay for HE, replicating DGR, but they could also spend the funds on something else. In fact, individuals cannot access such credit, because at the time of university entry, they do not yet command any personal future pension entitlements. Only in the aggregate we are confident that the cohort eventually will. This gives us a first inkling that DGR implements a form of risk-pooling. 
In the context of the debate on the sustainability of pensions, Harper, Howse and Baxter (2011) do include among their proposals the idea of raising the state pension age for graduates. However, to them this represents an indirect measure to approximate their objective of linking the state pension age to healthy life expectancy and/or lifetime earnings. Education is merely taken as a proxy. Therefore, both the purpose and the consequences of their scheme differ from DGR. Their concern is with sustainability and equity of state pensions. Mine is with financing HE. In principle, DGR is independent of the question whether, for reasons of demographic sustainability, the overall ratio of working life and retirement should shift towards the former, as long as the graduate/non-graduate differential is maintained.

Likewise of interest is the meaning of DGR in settings where eligibility for a state pension derives not (only) from reaching a threshold age, but from having worked a given number of years. If years of study currently count towards this tally, then no longer counting them might be seen as a variant of DGR. Whether the age threshold would in addition need to be raised for graduates would depend on the relative incidence of the two eligibility criteria among graduate retirees. If study time in any case does not count towards the years-worked criterion, there is no clash with DGR.

Note also that the mere existence of an education differential in average retirement age, which is already the case (see below), does not by itself serve the same purpose as DGR. If early retirement penalties were actuarially fair, then such a behavioural pattern would imply no financial penalty at all on graduates compared to non-graduates. Only a difference in statutory retirement age as the baseline for the calculation of benefits does so.

\subsection{Insurance characteristics}

To clarify my terminology, in distinguishing between "public" and "private" contributions, I do not refer to the amount of choice or the location of decision-making power, but purely to the question of who bears the resource burden. As Marginson (2007) has pointed out, this distinction between public and private funding does not predetermine whether HE produces a public and/or private good.

Charging fees "is not the same as recommending that students, or their families, should bear the costs" (Williams, 1988). A "fees \& vouchers" scheme would therefore still count as public funding. Conversely, DGR is a form of private contribution, even though the resource reallocation would actually flow from the public purse.

We must further distinguish between private and individual contributions. DGR represents an example of the former, but not the latter. Despite representing a private contribution, DGR collectivises some of the burden. This happens at two different levels: in form of risk-pooling within cohort groups, and risk-shifting to the state. 
As with a pure graduate tax, the amount an individual "repays" under DGR is not linked to the cost of their own particular course. Instead, a graduate cohort as a group raises the overall cost of their studies. The risk premium due to individual uncertainty concerning future income is thus pooled across all graduates. To some extent, this property is shared with graduate tax and income-contingent loans, if, as has been proposed, the risk premium is partly borne by the public. This risk premium is non-negligible and has been estimated to contribute between 2.5 and 3 percentage points to the interest rate on the loan using parameters for Belgium, Germany or the UK (Gerard and Vandenberghe, 2007). The question of risk sharing is critical in fact, because, while the pattern that graduates enjoy higher mean incomes is highly robust, it is decidedly not the case that the variation in individual incomes necessarily decreases with more education (Hartog, Van Ophem and Bajdechi, 2007). Without risk pooling, private underinvestment in $\mathrm{HE}$ even by rational individuals cannot therefore be ruled out. And if deferred retirement is applied strictly to graduates, then these need to cover the funds for those who did not complete their studies. This adds another risk premium to account for the "academic risk" of non-completion.

In a second departure from being a purely private contribution, under DGR the state assumes the financial transaction costs of converting anticipated future resources into present funds. Through these two mechanisms, pooling risk within cohorts and shifting onto the state the onus of converting future to present assets, DGR moderates the burden of increased costsharing on individuals.

An important consideration in the context of student loans and income-contingent fees is adverse selection. The adverse selection problem arises if those most likely to repay opt out of the scheme in favour of up-front payment. The pool of remaining borrowers then has an above-average risk of default. This increases the risk premium, providing an even greater incentive for those with a low personal risk to opt out of the system.

The risk of adverse selection is underdetermined by the minimal definition of DGR. Given an opt-out option, those choosing to participate in DGR might as a group be biased towards a lower likelihood of being economically active up to the regular retirement age and/or towards lower final salaries and pensions. As a result, the amount of deferral would have to be greater compared to the case where all graduates without exception are subject to mandatory DGR. For this to be the case, however, graduates from private HEIs that do not receive public funding would have to be subject to deferred retirement regardless. Assuming that those enrolling at private HEIs will on average come from higher socio-economic status backgrounds, this would constitute an additional redistributive measure. If, however, DGR were applied only to graduates from HEIs that benefit from the funding instrument, the adverse selection problem would not only rear its head again, but come hand in hand with increasing social stratification between public and private HEIs. 


\section{Economic Feasibility - A Preliminary Assessment}

\subsection{A first approximation}

A key question is how the net present value (NPV) of the future public savings under DGR compares to the value of tuition fees. We may establish the appropriate order of magnitude with a crude approximation.

The particular relevance of the discussion to the European context makes it convenient to express the calculations in Euros. For purposes of discussion, $€ 10000$ is the stylised "full cost" fee, close to the OECD average tertiary institution expenditure per student per annum (OECD, 2010). Given that the cost of instruction is typically only two thirds of the overall institution cost (the latter including research spending, for example) (Bevc and Uršič, 2008), this number is something of an overestimate. Anyhow, full cost recovery is not sought by most European governments, so DGR would in reality need to cover only a fraction of this, perhaps between 10 and 50 percent. For convenience, a level of $€ 3000$ per student per annum, currently exceeded within the EU only in the UK (although a punitive fee for long-term students at this level is under discussion in the Netherlands), will be taken as representative of a "high" level of fees. "Moderate fees" will be a shorthand for $€ 1000$ per student per annum. A four-year degree is therefore priced at $€ 40000$ under full-cost fees, $€ 12000$ with high fees, and $€ 4000$ with moderate fees.

The most straightforward definition of the NPV is adequate, namely to discount the future value with a given compounded rate of interest. The time horizon in question may be approximated by 50 years, which would correspond to university entry at 18 and retirement at 68 , for example. Assuming a nominal annual interest rate of 4 percent, in line with existing literature (e.g. Vandenberghe and Debande, 2007), the NPV amounts to approximately 14 percent of the nominal future asset at the end of 50 years.

This means that, for each $€ 10000$ that an annual graduate pension is worth, each year by which graduate retirement is deferred has a NPV of $€ 1400$. Conversely, financing one year of tertiary study at moderate (high) fees, requires just over $€ 7000$ ( $€ 21000)$ to be saved at the end of the 50 year period. This means that in order to off-set moderate fees for a four-year degree by deferring graduate retirement by a single year, an extra future graduate person-year in the labour force instead of retirement would have to be valued at around $€ 30000$. If this value is taken to be $€ 40000$, even high fees could be almost off-set by a two-year deferral.

Are these savings plausible? Across the EU and OECD, mandatory pensions at retirement on average replace close to 60 percent of the final salary (theoretical gross replacement rate), and this is not expected to change dramatically over the coming decades (EU, 2010; OECD, 2009). Conveniently, at 1 percent inflation, 60 percent is also approximately the in- 
flation adjustment over 50 years. We can therefore express the assumption that the average graduate pension in 50 years time will reach nominal $€ 30000$ (€40 000) as the assumption that the average final graduate salary just before retirement is $€ 30000$ (€40 000) today. For many European countries, this seems plausible, especially where these levels are exceeded even by the average wage (OECD, 2011).

\subsection{Further pricing considerations}

Evidently, the above calculation ignores important factors. Some of these add to the financial value of DGR, others detract from it. Yet others have an effect that is indeterminate, meaning either its direction depends on the precise values of contextual parameters, or that it would require more elaborate modeling to assess.

On the positive side, saved pension payments are only part of the public savings through later retirement. The added value of a longer working life to the economy at large is difficult to estimate. At the very least, however, there would be additional income tax revenue, since the tax on the additional wages would certainly exceed any tax paid on pensions.

In addition, the assumed interest rate errs on the side of caution. Note that DGR is less attractive to governments experiencing financial crisis, since it does not by itself produce liquid funds. The relevant interest rate, applicable to a country with good credit rating, should therefore be towards the low rather than high end of the historic range of European government bonds. In this sense, 4 percent is a soundly conservative parameter. If instead we assume an interest rate of 2.5 percent, the present values would all more than double (to 29 percent instead of the 14 percent of the future nominal value). Under this - still reasonable - assumption, even high fees for a full degree course could be offset by a deferring graduate retirement by a single year.

The assumed inflation rate is also conservative. The target rate set by the European Central Bank is closer to 2 percent. Higher inflation at a given interest rate makes DGR more feasible, because it is of course the real interest that is important. Assuming 2 percent inflation instead of 1 percent, while holding on to 4 percent nominal interest, therefore has a similar effect, albeit slightly less pronounced, to a reduction of the interest rate from 4 to 2.5 percent discussed above.

Graduates at the end of their career will typically have wages above the overall average, however, in this regard working with the "typical" and/or average values for theoretical replacement rates and wages is, in combination, a safe assumption. While the theoretical replacement rates are substantially lower for high wage earners, the absolute pension value (and therefore the value of DGR) will still be higher. For example, a stylised high wage 
earner with a final salary twice the average will typically experience a gross replacement rate that is about 25 percent lower (EU, 2010).

On the negative side, if salary increases over the additional working years raise later pension payments, graduate pensions would, under DGR, be paid for a shorter time, but be slightly higher. Additional working years under DGR could of course be declared ineligible for pension entitlements, but this is not part of the definition of the scheme.

Also, not all graduates would spend the years between their old and new retirement age in employment. Some would receive unemployment benefits or other transfers instead of a pension, negating the saving in the latter.

Transaction costs are also likely. The naïve approximation assumes smooth transfers from public pension funds to the HE budget. This may not be trivial, especially if the latter is organized at a different level or even multiple levels of governance. In Germany, for instance, HE funding comes "from the budgets of various ministries at federal and state level, from nearly all branches of social security, as well as in form of tax breaks of different kinds" (Gwosć and Schwarzenberger, 2009, p. 342).

In addition, the reduction in future liabilities needs to be actively "cashed in", and governments rely on the financial markets to perform this conversion. How exactly this particular form of asset would be priced is open to debate. The revenue is only accessed at the very end, so interest payments on a bond would themselves need to be financed in the meantime. The long time horizon to maturity by itself is unexceptional, however, and in line with a recent trend towards "ultra-long term" bonds (Hughes and Mackenzie, 2011).

Other issues require careful modeling, for instance the question whether to truncate or shift the schedule of pension payments, and whether, subject to real-life credit constraints and uncertainty, the DGR scheme creates incentives for over or under-investment in $\mathrm{HE}$ at the individual or public level if retirement decisions are endogenous. Such economic modeling is a major undertaking in its own right and is beyond the scope of this paper.

The financial value of the scheme is also affected by the extent to which it can be actively subverted. Two issues immediately come to mind.

The first relates to migration. Are individuals not incentivised to study (without fees) in DGR countries, but then work and retire (without penalty) in a non-DGR country? As a matter of fact, there is little evidence of significant migration flows induced by fee avoidance. If anything, some of the countries exhibiting the least "affordability" of HE (Vossensteyn, 1999), such as England or Austria, have among the highest shares of foreign EU students, demonstrating that other aspects (language, perceived quality, etc.) outweigh these concerns. In any case, the share of migrants among the total graduate labour force remains relatively small. And in the long run, it seems reasonable to assume the emergence of some kind of "common pension area" in the EU. Indeed, recent discussions at EU level on harmonising 
economic governance have explicitly included the subject of pensions (SPON, 2011). As long as intra-EU flows continue to account for a major share of labour migration, this would go some way towards addressing these objections.

The other threat of "free riding" concerns the theoretical moral hazard of students and employers colluding to fill graduate jobs with individuals who completed their studies, but chose not to officially graduate in order to avoid the retirement penalty. They would receive salaries slightly lower than certified graduates, at a level that makes the scheme lucrative for both employee and employer. In reality, this is unlikely to occur on a grand scale. The tactic would fail for the professional degrees of law, medicine, architecture, engineering, and other regulated professions. It would preclude employment in the public sector. Moreover, the centrality of certification arises almost inevitably from the systemic logic of any formal education system (Green, 1980).

To sum up, the fact that some factors would lead to a lower and others to a higher estimate than the naïve calculation suggests the latter is neither an obvious over- nor an obvious underestimate. It may therefore pass as an acceptable first approximation, especially if we work with a generous margin of error. Accordingly, the conclusions are drawn on the assumption that the NPVs are only half of their naïve estimate.

In conclusion, as a first approximation based on a simple net present value calculation, but with conservative assumptions and a 100 percent margin for error, deferring graduate retirement by two years could substitute for moderate tuition fees for four-year degrees. If we allow slightly less conservative assumptions for pension entitlements and the interest rate (but holding on to the 100 percent buffer), this remains true even for high fees. Off-setting full cost fees would require more optimistic assumptions (higher pension saving, lower interest rate, no buffer), as well as a three-year deferral. Not a plausible policy option, but even this scenario is not wholly unrealistic, showing that the conclusion for moderate tuition fees is probably robust.

\section{Discussion}

The previous sections have focused on characteristics DGR enjoys by design and on potential effects that directly affect its financial value. The following more speculatively explores the scheme's general implications for HE and its promise of policy expedience.

The effect on tertiary participation need not be severe. Compared to high tuition fees, delayed or not, DGR should be more easily acceptable to a majority of affected individuals than tuition fees or a graduate tax, both as current prospective students and as future retirees.

The phenomenon of "mental accounting", for example, suggests students will not frame deferred retirement in terms of a financial loss, but as a case of "working longer". Under 
DGR, the costs that are very far in the future indeed from the perspective of an 18 or 19year-old, compared to the immediate benefit. DGR allows individuals to "borrow" money to invest in their $\mathrm{HE}$, but in a way that does not manifest itself as tangible, personal debt. Moreover, students maintain the freedom to base their choice of course on criteria other than income generation.

Patterns of retirement behaviour suggest DGR would also be acceptable to affected individuals as prospective retirees. Across OECD countries, tertiary graduates are already consistently and significantly more likely to still be in the labour force at higher ages than nongraduates (OECD, 2006). The fact that controlling for cohort trends and partnership status leaves only a modest difference of one year in retirement age for male graduates (and none for females) (Brugiavini and Peracchi, 2005), does not invalidate this observation. The selection effects would remain the same under DGR, after all. While this does not indicate that highly educated workers are eager to retire even later, it does show they are willing and able to remain economically active at higher ages than others.

In addition, even though income-contingent fees should, if the income threshold is appropriately chosen, by definition not constitute an unmanageable burden, repayment will overlap with the "rush hour of life", when mortgages and family formation place additional strain on the finances of young adults. By contrast, the timing of DGR is more convenient from an individual point of view, because it shifts the burden to a time when, towards the end of their career, financial independence is at a peak.

The distributional implications of DGR depend on how the issue is framed. In terms of direct or indirect transfers, there is no flow of resources from non-graduates to graduates that would make the scheme evidently inequitable. However, in terms of income distributions with and without DGR, on the face of it the effect is regressive, because deferring their retirement will increase the life-time income of graduates compared to non-graduates.

This ignores the value of the free time, however. If the current retirement behaviour is assumed to reflect the optimal choice of individuals, given their preferences for income versus free time, then imposing DGR does imply a net loss of utility for graduates, even in the face of a higher total income. Ultimately, barring detailed knowledge of retirement preferences and the value graduate retirees attach to their free time, the distributional implications of DGR are undetermined.

To the general public, later retirement for graduates is likely to be perceived as almost self-evidently fair; after all, graduates also experience a later labour market entry. Arguably, serious study constitutes unpaid, but nevertheless economically productive, work; Moreover, graduates may not spend so much less time in labour market as their later entry suggests if they suffer less unemployment, both in frequency and duration, and if lower fertility results in fewer maternity breaks. However, in terms of political feasibility, it is ultimately perceived 
fairness that matters. The above caveats are unlikely to be able to dent the persuasiveness of the simple formula "enter later, exit later".

Different statutory retirement ages for different groups of people are not intrinsically socially unacceptable. The most common example is differentiation by gender. There are also examples of differentiation according to life and/or career choices. In the Czech Republic, the retirement age for women is contingent on the number of children (OECD, 2009) (n.b. this is different from counting years spent on child-care towards the pension level). In extreme cases, changing the retirement age for specific occupations may serve purely as an instrument of manpower planning (Ganjapure, 2010). The idea of a variable pension age has already been injected into the policy debate in the context of sustainability (Harper, Howse and Baxter, 2011), even contingent on individual factors much more speculative, such as healthy life expectancy. In any case, the proposed deferral of between one and three years in the context of DGR is considerably less than the existing variation in state pension age between OECD members.

A consequence of DGR that ought to appeal to legislators, planners and administrators is that it increases their freedom in designing policy and flexibility in implementing it.

To see this, note that tuition fees, over and above shifting expenses from the public to private individuals, have effects on HEIs and prospective students, that might or might not be desired. Introducing substantial tuition fees, for example, compels potential students to estimate their future income under different enrolment options, and possibly to go out and get a loan. Institutions may need to introduce new administrative and financial processes if they collect the fees themselves, and make business and marketing decisions if fees are variable. At the very least, HEIs will have to assess the relative profitability of different courses they offer.

Depending on your political persuasion, these implications may be desirable or a "necessary evil". Either way, they come as a package, and have to be trimmed around the edges (a new scholarship program here, a subsidy there) to resemble the political effect actually sought as a compromise between different political camps and affected government departments.

Conveniently, under DGR the core effect of shifting the resource burden is isolated from other effects on the HE sector, which can then be initiated as and when desired. The scheme has no pre-determined effect on governance, for example, but is compatible with different policy aims.

Consider DGR in its purest form, where the only action taken is to increase the statutory retirement age for those graduating from now on. At this point, the only tangible change is that future public liabilities per graduate have diminished. A significant share of the resource burden of $\mathrm{HE}$ is thus shifted from the public onto private shoulders, but without directly 
affecting the HE system or educational dynamics in any way. At this stage, current flows of public payments to HEIs have neither increased nor decreased, and no action whatsoever is required of either prospective students or HEIs. From their perspective, the shift in resourced burden is achieved "at the stroke of a pen".

Stopping there would, of course, do nothing to improve the financial situation of HEIs or cash-strapped governments. However, the point is precisely that the decision whether and when to make available additional resources, or to reduce public payments, can now be made independently of the policy that achieved the new balance between public and private contributions in general. The ministry of finance can be gratified immediately while the ministry of HE can take its time to determine appropriate policy on its own terms.

Under DGR, the mechanism through which private contributions are increased does not pre-determine how they should be dispersed. We can spare HEIs the challenge of adaptation if we wish, but if we want to achieve secondary objectives of institutional autonomy, or increased economic accountability, we can do that too.

Moreover, because the private contribution under DGR is postponed by a long time, the option remains open for future governments to renew their commitment to HE as a public good and waive the retirement deferral. Unlike fees or graduate taxes that would be practically impossible to reimburse, DGR constitutes a shift from public to private funding that is in principle reversible, and should therefore be easier to enact.

Finally, as mentioned previously, DGR does not as such contribute to the sustainability of the pension system, since the savings are redirected to HE. Nevertheless, DGR would have the politically welcome side-effect of raising the effective average retirement age and thereby promote a social norm for later retirement. This effect is magnified by the fact that the share of graduates in younger cohorts today is higher than in cohorts currently approaching retirement.

\section{Conclusion}

Clearly, despite combining many attractive characteristics, DGR does not dominate all alternatives on all criteria, much less in all settings. In any case, there is a need for student loans, for instance, even in the absence of fees, because the indirect costs of HE, notably living expenses, greatly exceed the cost of tuition fees. However, it offers a genuinely different combination of characteristics than any of the alternatives. As such, DGR potentially presents an genuine addition to the policy toolbox, an addition that is all the more useful as the set of policy options currently available has proven insufficient to create a broad consensus among the different stakeholders and political camps. 
In introducing a novel scheme that differs so fundamentally from existing proposals, it seemed necessary to begin with a comprehensive general discussion in order to establish the principle, without focusing prematurely on specific parameter values. An obvious next step is to fully quantify the factors discussed in Section 4.2 based on empirical data and forecasts for specific countries, to arrive at a more robust estimate of the net public saving associated with each additional graduate year in the labour force. Next, including DGR within a formal life-cycle model with endogenous human capital investments and retirement decisions will be required to deepen our understanding of the scheme's implications.

Many important questions remain to be addressed, and the present contribution has, at best, provided a first "inventory of issues". However, none of the most obvious concerns appear to deal a death-blow to the idea. Accordingly, I hope this piece will serve merely as an opening gambit. 


\section{References}

Asplund, R., O.B. Adbelkarim and A. Skalli (2008). 'An equity perspective on access to, enrolment in and finance of tertiary education'. In: Education Economics 16.3, pp. 261274.

Bevc, M. and S. Uršič (2008). 'Relations between funding, equity, and efficiency of higher education'. In: Education Economics 16.3, pp. 229-244.

Browne, John et al. (2010). Securing a sustainable future for higher education: An Independent Review of Higher Education \& Student Finance in England. www.independent.gov.uk/browne-report.

Brugiavini, A. and F. Peracchi (2005). 'The length of working lives in Europe'. In: Journal of the European Economic Association 3.2-3, pp. 477-486.

Callan, T., T. Smeeding and P. Tsakloglou (2008). 'Short-run distributional effects of public education transfers to tertiary education students in seven European countries'. In: Education Economics 16.3, pp. 275-288.

Dabla-Norris, E. and M. Gradstein (2004). The Distributional Bias of public education: causes and consequences. International Monetary Fund.

Davies, Peter, Jean Mangan and Amanda Hughes (Dec. 2008). 'Participation, financial support and the marginal student'. In: Higher Education 58.2, pp. 193-204.

Der Spiegel, Online Edition (SPON) (2011). Merkel boxt Euro-Wirtschaftsregierung durch. Spiegel Online - 4. Februar.

Economic Policy Committee (Ageing Working Group), Social Protection Committee (Indicators Sub-Group) and Commission services (DG for Economic and Financial Affairs and DG Employment, Social Affairs and Equal Opportunities) (2010). 'Future adequacy of pensions measured by Theoretical Replacement Rates'. In: Joint Report on Pensions: Progress and key challenges in the delivery of adequate and sustainable pensions in Europe. 71. European Union. Chap. Annex 5.

Ganjapure, Vaibhav (2010). Govt may raise principals' retirement age to 62. The Times of India, 26. Sep 2010.

Gerard, M. and V. Vandenberghe (2007). 'Introduction: Economics Of Higher Education'. In: Education Economics 15.4, pp. 383-384.

Green, Thomas F. (1980). Predicting the Behaviour of the Educational System. Syracuse, NY: Syracuse University Press.

Gwosć, C. and A. Schwarzenberger (2009). 'Die Finanzierung der Hochschulbildung in Deutschland'. In: Wirtschaftsdienst 89.5, pp. 334-342. 
Harper, Sarah, Kenneth Howse and Steven Baxter (2011). Living longer and prospering? Designing an adequate, sustainable and equitable UK state pension system. Oxford Institute of Ageing.

Hartog, J., H. Van Ophem and S.M. Bajdechi (2007). 'Simulating the risk of investment in human capital'. In: Education economics 15.3, pp. 259-275.

Häyrinen-Alestalo, Marja and Ulla Peltola (Sept. 2006). 'The Problem of a Market-oriented University’. In: Higher Education 52.2, pp. 251-281.

Hossler, D. et al. (1997). 'State funding for higher education: The Sisyphean task'. In: Journal of Higher Education 68.2, pp. 160-190.

Hughes, Jennifer and Michael Mackenzie (2011). US asked to follow ultra-long bond trend. Financial Times Online Edition, 3 February.

Johnstone, D (Aug. 2004). 'The economics and politics of cost sharing in higher education: comparative perspectives'. In: Economics of Education Review 23.4, pp. 403-410.

Marginson, S. (2007). 'The public/private divide in higher education: A global revision'. In: Higher Education 53.3, pp. 307-333.

Neill, C. (2009). 'Tuition fees and the demand for university places'. In: Economics of Education Review 28.5, pp. 561-570.

Organisation for Economic Co-operation and Development (OECD) (2006). Live longer, work longer.

- (2009). Pensions at a Glance 2009: Retirement-Income Systems in OECD Countries.

- (2010). Education at a Glance 2010: OECD Indicators.

- (2011). Pension Database. http://stats.oecd.org/.

Schwartz, Steven (2011). The Higher Purpose. Times Higher Education, 1 January.

Shen, Hua and Adrian Ziderman (May 2008). 'Student loans repayment and recovery: international comparisons'. In: Higher Education 57.3, pp. 315-333.

Tilak, Jandhyala B. G. (Apr. 2009). 'Higher education: a public good or a commodity for trade?' In: Prospects 38.4, pp. 449-466.

Vandenberghe, V. (2005). Free Higher Education-Regressive Transfer or Implicit Loan? Discussion Paper 31. UC Louvain, Département des Sciences Economiques.

Vandenberghe, V. and O. Debande (2007). 'Deferred and Income-Contingent Tuition Fees: an empirical assessment using Belgian, German and UK data'. In: Education Economics 15.4, pp. 421-440.

Vossensteyn, JJ (1999). 'Where in Europe would people like to study? The affordability of higher education in nine Western European countries'. In: Higher Education 37.2, pp. 159-176.

Williams, G. (1988). 'The Debate about Funding Mechanisms'. In: Oxford Review of Education 14.1, pp. 59-68. 


\section{VIENNA INSTITUTE OF DEMOGRAPHY}

\section{Working Papers}

Riosmena, Fernando, Maria Winkler-Dworak, Alexia Prskawetz, and Gustav Feichtinger, The Impact of Policies Influencing the Demography of Age Structured Populations: Lessons from Academies of Science, VID Working Paper 04/2011.

Buber, Isabella and Katrin Fliegenschnee, Are you Ready for a Child? A Methodological Triangulation on Fertility Intentions in Austria, VID Working Paper $03 / 2011$.

Fent, Thomas, Belinda Aparicio Diaz, and Alexia Prskawetz, Family Policies in the Context of Low Fertility and Social Structure, VID Working Paper 02/2011.

Buber, Isabella, Caroline Berghammer, and Alexia Prskawetz, Doing Science, Forgoing Childbearing? Evidence from a Sample of Female Scientists in Austria, VID Working Paper 01/2011.

Strulik, Holger, Klaus Prettner, and Alexia Prskawetz, R\&D-Based Growth in the Post-Modern Era, VID Working Paper 09/2010.

Prettner, Klaus and Alexia Prskawetz, Demographic Change in Models of Endogenous Economic Growth. A Survey, VID Working Paper 08/2010.

Flandorfer, Priska, Christian Wegner, and Isabella Buber, Gender Roles and Smoking Behaviour, VID Working Paper 07/2010.

Barakat, Bilal, Johannes Holler, Klaus Prettner, and Julia Schuster, The Impact of the Economic Crisis on Labour and Education in Europe, VID Working Paper 06/2010.

Grafeneder-Weissteiner, Theresa and Klaus Prettner, Agglomeration Processes in Ageing Societies, VID Working Paper 05/2010.

Buber, Isabella, Parity-specific weights for the Austrian Generations and Gender Survey, VID Working Paper 04/2010.

Testa, Maria Rita, She wants, he wants: Couple's childbearing desires in Austria, VID Working Paper 03/2010.

Buber, Isabella, Wissenschaftlerinnen in Österreich - Zusatzerhebung im Rahmen des GGS.Dokumentation der Datenerhebung und deskriptive Ergebnisse, VID Working Paper 02/2010.

The Vienna Institute of Demography Working Paper Series receives only limited review. Views or opinions expressed herein are entirely those of the authors. 